Institute of Physics on May 15, taking as his subject "Physics and Science Museums". Sir Henry referred in particular to the work which the Board of the Institute has done through a special committee in locating pieces of physical apparatus of special historical importance, and ensuring so far as possible that they should be preserved from deterioration or possible loss. This committee was appointed in 1925 , and since then it has brought to light many objects which were little known to physicists generally and of which the historical importance was not always appreciated at its full value. It was not until the middle of the eighteenth century that the first institution was established for the preservation of scientific instruments and technical apparatus; this was the museum of the Conservatoire des Arts et Metiers in Paris, which was founded in 1794 to include all kinds of machinery, models, tools, instruments, etc. Little can now remain of the instruments and apparatus in use in earlier times, not only because in those times there was no institution where they could be deposited, but also because for the most part their historical importance was seldom realised. Then probably more than now, an instrument once acquired was treasured for there were few of them, but it passed in time to a later generation which neither appreciated it nor understood its importance. The same influence operates to-day and there is much difficulty in securing for posterity the more important examples of apparatus which has played a part in the advance of science. The address will be published in due course and copies will be obtainable from the Institute of Physics, 1, Lowther Gardens, Exhibition Road, London, S.W.7 (1s. 1 d. including postage).

\section{A New Nature Reserve in New Zealand}

THe property of Brooklands, New Plymouth, New Zealand, was handed over by the trustees of the late Mr. Newton King to the Borough of New Plymouth as a public reserve and officially opened by His Excellency the Governor-General, Lord Bledisloe, on March 10. It adjoins the beautiful Pukekara Park, and forms a natural extension of it. Together they comprise an area of more than 100 acres, forming a park second to none in the Dominion either in size or natural beauty. In addition to the actual property of Brooklands, the Trustees presented five acres of native bush nearby, and, to give access to it and make the whole one large reserve, Mr. T. C. List and Mr. C. A. Wilkinson gave an area of seven and a half acres. In his speech, Lord Bledisloe, after paying tribute to the late Mr. King, pointed out some of the many natural advantages which the Dominion possesses, and said that it is unique in the number, variety and grandeur of its many beauty spots within a relatively small area and in its incomparable native bush; he prophesied that eventually New Zealand will find its tourist traffic the main source of its wealth. While admiring the fine specimens of introduced trees, Lord Bledisloe gave a word of warming against the mixing of exotic trees with the native vegetation. All those who have the preservation of the native vegetation of the Empire at heart will feel grateful for the interest which Lord Bledisloe has in their efforts, and for the help he is giving them.

\section{Safety in X-ray work}

IN a paper to the Institution of Electrical Engineers read on February 22, by Mr. L. G. H. Sarsfield, safety measures for workers with $\mathrm{X}$-ray plant were discussed. He discussed the risks of fatal injury and the advantages and disadvantages of using signal lights. The concluding portion of the paper dealt with the use of high voltage flexible cable and described some new types of cable which are coming into use. Stress was laid on the need for definite instructions so as to avoid electrical dangers. $\mathrm{He}$ suggested that the Institution should co-operate with the British Institute of Radiology in framing rules. In the discussion, Dr. V. E. Pullin said that at Woolwich they had to legislate for uninstructed use, and so had to make the equipment absolutely safe. Dr. G. W. C. Kaye, speaking as secretary of the International Protection Committee which will meet at Zurich next July, pointed out that international recommendations were framed as the result of the British Protection Committee's work, and these recommendations play a very important part in the design of equipment all over the world. The League of Nations has issued a very comprehensive publication on the subject. The British recommendations are now being revised and he hopes that the use of rubber floor mats and insulating shoes will have more consideration. Dr. B. J. Leggett said that too much talk of the need of protection made patients nervous. In some cases, too much protection will prevent results being obtained. In reply, Mr. Sarsfield said that there is a real need for earthing the conductor at intervals along its length.

\section{Rothamsted Experimental Station}

THE appeal for funds to purchase the Rothamsted fields has now secured in cash or good promises the $£ 10,000$ necessary to claim the munificent donations of $£ 15,000$ by Mr. Robert McDougall and $£ 5,000$ by the Sir Halley Stewart Trust (see Nature, 133, 442, March 24, 1934). The success of the purchase scheme is therefore assured, and the appeal is being kept open only a few days longer in order to enable the Committee to obtain the further amount needed to meet the agreed addition to the purchase price consequent on the ascertainment of the tithe charges, timber evaluation and other items. Several organisations still have to make their final decisions, but it is confidently expected that the whole amount including these additional payments will be secured within the next few days, so that the Rothamsted Committee can enter into possession free of all financial obligation and free therefore to devote the whole of its resources to the important agricultural investigations in hand.

\section{Annual Meeting of the British Medical Association}

THE one hundred and second annual meeting of the British Medical Association will be held in Bournemouth during the week commencing July 23 